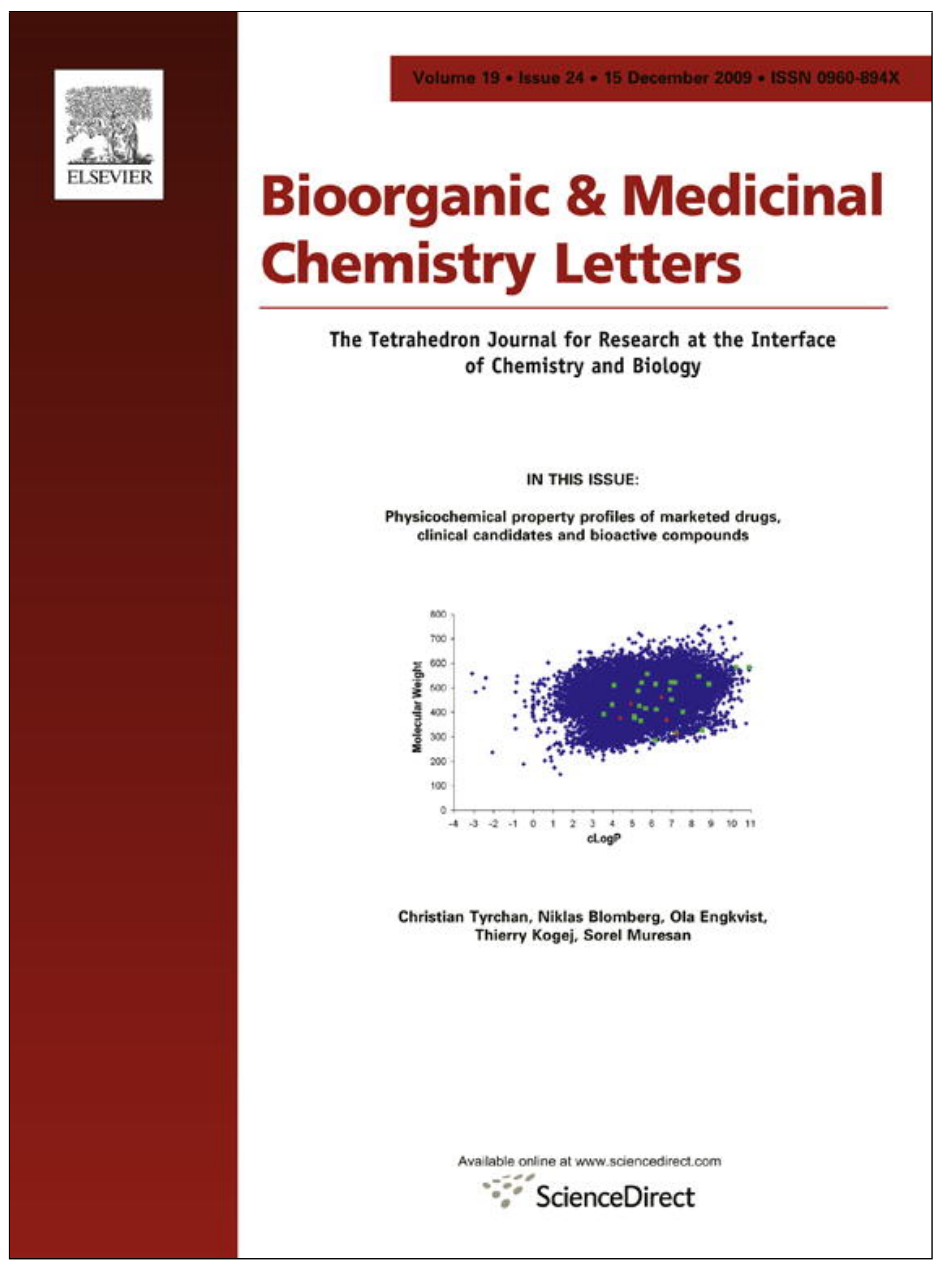

This article appeared in a journal published by Elsevier. The attached copy is furnished to the author for internal non-commercial research and education use, including for instruction at the authors institution and sharing with colleagues.

Other uses, including reproduction and distribution, or selling or licensing copies, or posting to personal, institutional or third party websites are prohibited.

In most cases authors are permitted to post their version of the article (e.g. in Word or Tex form) to their personal website or institutional repository. Authors requiring further information regarding Elsevier's archiving and manuscript policies are encouraged to visit:

http://www.elsevier.com/copyright 


\title{
Anti-tumoral activity of imidazoquines, a new class of antimalarials derived from primaquine
}

\author{
Iva Fernandes ${ }^{a}$, Nuno Vale ${ }^{a}$, Victor de Freitas ${ }^{a}$, Rui Moreira ${ }^{b}$, Nuno Mateus ${ }^{a}$, Paula Gomes ${ }^{a, *}$ \\ ${ }^{a}$ CIQUP, Departamento de Química, Faculdade de Ciências, Universidade do Porto, P-4169-007 Porto, Portugal \\ b iMed.UL, CECF, Faculdade de Farmácia de Lisboa, P-1600-083 Lisboa, Portugal
}

\section{A R T I C L E I N F O}

\section{Article history:}

Received 3 September 2009

Revised 16 October 2009

Accepted 17 October 2009

Available online 22 October 2009

\section{Keywords:}

Anti-tumoral

Breast cancer

Imidazolidin-4-ones

Malaria

Primaquine

Quinolines

\begin{abstract}
A B S T R A C T
The growth inhibitory activity of imidazoquines, antimalarial imidazolidin-4-ones derived from primaquine, on human cancer cell lines HT-29, Caco-2, and MCF-7 has been evaluated. Primaquine, $N$-dipeptidyl-primaquine derivatives, and other quinolines have been included in the study for comparison purposes. Primaquine and some of its derivatives were significantly active against the MCF-7 human breast cancer cell line, so these compounds might represent useful leads targeted at the development of novel specific agents against breast cancer. Conversely, all compounds were generally inactive against HT-29, with only one of the imidazoquines having $\mathrm{IC}_{50}$ below $50 \mu \mathrm{M}$. Activities against the Caco- 2 cell line were modest and did not follow any defined trend.
\end{abstract}

(c) 2009 Elsevier Ltd. All rights reserved.
Quinolines and derivatives have been classically known for their antimalarial properties. ${ }^{1-3}$ Quinolines may have other relevant biological effects, such as the potent and selective antagonism to $\alpha_{2 \mathrm{c}}$-adrenoreceptors of some 4 -aminoquinolines with potential applications in the therapy of CNS disorders. ${ }^{4}$ Recently, Strobl and co-workers found that the cinchona tree bark antimalarial quinidine inhibited growth of human breast tumor cells, ${ }^{5}$ which prompted them to engage in the study of other anti-proliferative quinolines and to the proposal of four of such compounds as breast tumor cell differentiation agents. ${ }^{6}$ Mahajan et al. have also described new 7-chloroquinolyl thioureas structurally related to chloroquine as potential antimalarial and anticancer agents. ${ }^{7}$ The mechanism of anti-tumoral action of quinolines is not fully established, ${ }^{8}$ but reported increase of caspase 3 levels in breast cancer cells suggests involvement in apoptosis. ${ }^{9}$ Reports on new drug candidates with dual antimalarial and anticancer activity are not limited to quinoline derivatives, as shown by most recent works by O'Neill's and Posner's groups with trioxanes. ${ }^{10,11}$ While the former authors have found artemisinin-acridine hybrids that displayed in vitro antimalarial and anti-tumor activity, ${ }^{10}$ the latter have conceived new dimeric trioxane sulfones able to cure malaria-infected mice with a single oral dose and to display potent and selective cytotoxicity against several cancer cell lines. ${ }^{11}$

\footnotetext{
* Corresponding author.

E-mail address: pgomes@fc.up.pt (P. Gomes).
}

At the light of the above findings and of our former promising results with imidazoquines, derivatives of the 8 -aminoquinoline antimalarial primaquine, $\mathbf{1}$, as a new class of antimalarials not susceptible to oxidative deamination, ${ }^{12-19}$ we decided to investigate their activity as anti-proliferative agents against the human tumoral cell lines HT-29 (human colon adenocarcinoma), Caco-2 (human epithelial colo-rectal adenocarcinoma), and MCF-7 (breast cancer). The study was focused on imidazoquines $2-4$, but also included the parent drug (1), its $N$-acetyl (5) and two $N$-dipeptidyl (6 and 7) derivatives, as well as other three quinolines (8-10) for comparison and establishment of preliminary SAR.

Primaquine (1) and quinolines 8-10 were commercially available from Sigma-Aldrich, whereas primaquine derivatives (2-7) were prepared in good yields and with correct spectral data, by previously reported methods ${ }^{12-19}$ described in Supplementary data.

Cytotoxicity assays were performed according to the procedure adopted by the National Cancer Institute (NCI, USA), ${ }^{20,21}$ as detailed in Supplementary data, where inhibition curves obtained for all compounds against all three cell lines are also given.

Figure 1 displays the inhibition curve obtained for 3a on MCF-7 cells, as an example. $\mathrm{IC}_{50}$ values were deduced from these curves and are given in Table 1 . From these data, it can be inferred that compound activity against the cell lines assayed depends on both compound structure and specific cell line. The clearest observation is that compounds have highest growth inhibitory effects (lower $\mathrm{IC}_{50}$ values) on the breast cancer cell line (MCF-7), while are 


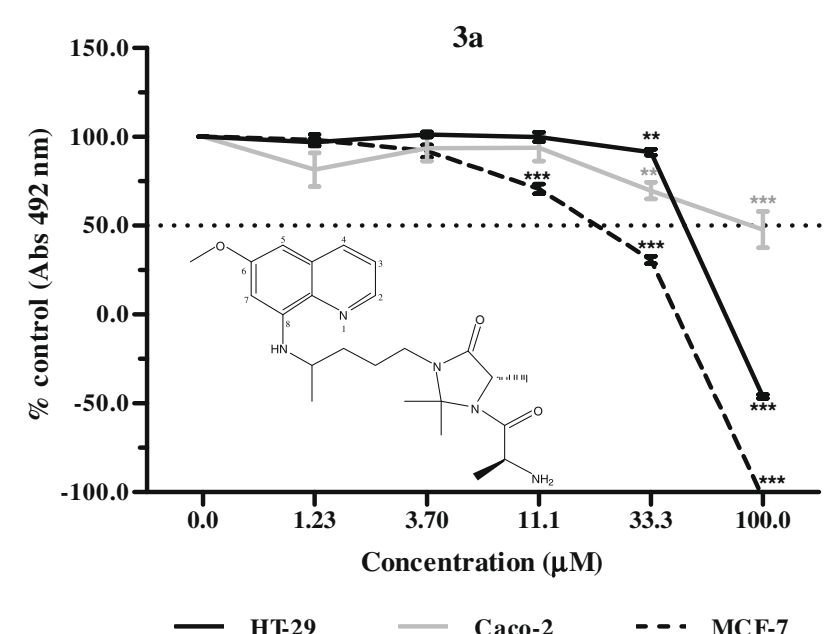

Figure 1. Effect of imidazoquine 3a on the growth of different human tumoral cell lines evaluated by Sulforhodamine B assay. Cells, seeded in 96-well plates, were treated with a broad concentration range $(6.3-100.0 \mu \mathrm{M})$ of each compound for $48 \mathrm{~h}$. Each value represents the mean \pm SEM $(n=3-6) .{ }^{* *} p<0.001,{ }^{* * *} p<0.0001$ (significant decrease vs control).

practically inactive against the colon adenocarcinoma cell line (HT29). In what concerns growth inhibition of Caco-2 cells, results are more disperse and no clear structure-activity relationships could be drawn in this case.
Interestingly, while quinolines 8-10 were generally inactive against any of the three cell lines, primaquine (1) had the highest activity against MCF-7 and Caco-2 cells and the second highest activity against HT-29 cells, suggesting a key role of the aliphatic chain of primaquine (the 4-amino-1-methylbutyl substituent at the quinolinic's 8-amino group) for its anti-tumoral activity. This becomes quite clear when comparing 8-amino-6-methoxyquinoline (8) with primaquine (1).

Modification of the primaquine's terminal primary amine, by insertion of either imidazolidin-4-one $(\mathbf{3}, \mathbf{4})$ or dipeptide $(\mathbf{6}, \mathbf{7})$ moieties generally had a detrimental effect on anti-tumoral activities, which was more pronounced for imidazolidin-4-one peptidomimetic structures $(3,4)$. Exception is made for imidazoquine 3a that was the best against HT-29 cells and one of the best against MCF-7 cells. For these two cell lines, comparison of data for 3a with those for $\mathbf{3 b}$ show that replacement of the $N^{1}$-aminoacyl substituent of the imidazoldin-4-one ring by an $N^{1}$-acetyl group leads to activity loss, thus indicating that the primary amine from the $\mathrm{N}$ terminal amino acid has a relevant role for the anti-tumoral activity of peptidomimetic imidazoquines as 3a. This is possibly a key structural requirement for activity against MCF-7 cells, as the compounds displaying lowest $\mathrm{IC}_{50}$ values on this cell line, that is, primaquine (1), imidazoquine $3 a$ and $N$-dipeptidylprimaquines 6,7 all have an aliphatic primary amine whose acetylation leads to significant loss of activity ( $\mathbf{5}$ vs $\mathbf{1}, \mathbf{3 b}$ vs $\mathbf{3 a}$ ). We believe that it is the presence of such a primary amine rather than the existence of an amino acid or dipeptide moiety that is relevant, otherwise primaquine would not rank the best. Interestingly, the primary amine

Table 1

In vitro activity of test compounds against HT-29, Caco-2, and MCF-7 human tumoral cell lines (average \pm SEM from 3 to 6 independent experiments)
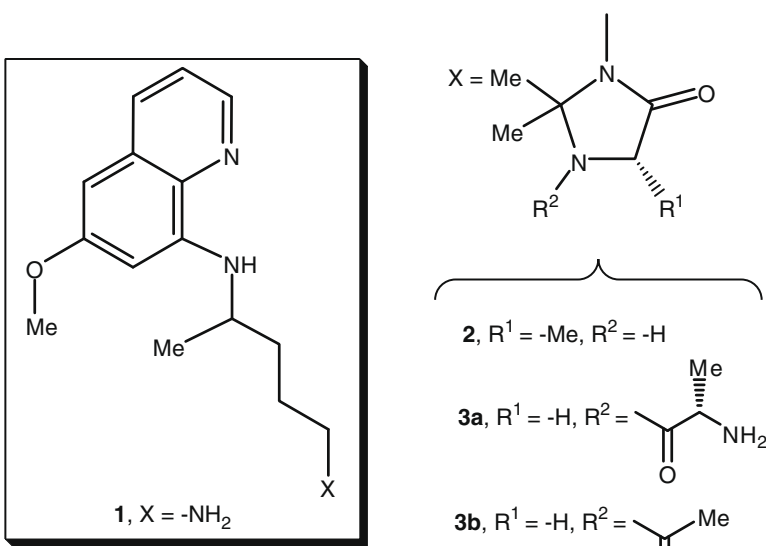

$$
\text { 2, } R^{1}=-M e, R^{2}=-H
$$

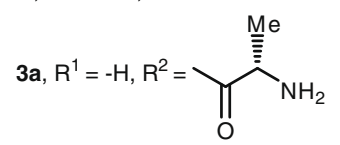

3b, $R^{1}=-H, R^{2}=\prod_{O}^{M e}$<smiles>[Y4]CNC(=O)CN1C(=O)[C@@H]([Y16])NC1([R])[2H]</smiles>

4a, $R^{3}=R^{4}=-M e$

$4 \mathrm{~b}, \mathrm{R}^{3}$ and $\mathrm{R}^{4}=-\left(\mathrm{CH}_{2}\right)_{5}$<smiles>[R6]CNC(=O)CNC(=O)C(N)N</smiles><smiles>[Y]#CNC(=O)C1CCCN1C(=O)[C@@H](C)N</smiles><smiles>[Y]CNC(C)=O</smiles><smiles>CC1(P)C=Cc2ccccc2N=C1</smiles>

$8, \mathrm{R}^{5}=6-\mathrm{OMe}, \mathrm{R}^{6}=8-\mathrm{NH}_{2}$ $9, \mathrm{R}^{5}=2-\mathrm{Cl}, \mathrm{R}^{6}=3-\mathrm{COOH}$ $10, R^{5}=4-C l, R^{6}=7-C_{3}$

\begin{tabular}{|c|c|c|c|c|c|c|c|}
\hline \multirow[t]{2}{*}{ Compd } & \multicolumn{3}{|c|}{$\mathrm{IC}_{50} \pm \mathrm{SEM}(\mu \mathrm{M})$} & \multirow[t]{2}{*}{$\mathrm{mMW}(\mathrm{g} / \mathrm{mol})$} & \multirow[t]{2}{*}{$\log P^{\mathrm{a}}$} & \multirow[t]{2}{*}{$\log S^{\mathrm{a}}$ (solubility in $\mathrm{mg} / \mathrm{L}$ ) } & \multirow[t]{2}{*}{ Drug score $\mathrm{b}^{\mathrm{b}}$} \\
\hline & HT-29 & Caco-2 & MFC-7 & & & & \\
\hline 1 & $69.7 \pm 1.4$ & $48 \pm 16$ & $6.90 \pm 0.55$ & 259.35 & 2.76 & $-3.66(56.4)$ & 0.48 \\
\hline 2 & $>100$ & $71 \pm 18$ & $42.3 \pm 2.0$ & 370.49 & 3.25 & $-4.10(29.8)$ & 0.76 \\
\hline 3a & $46.3 \pm 0.7$ & $>100$ & $20.0 \pm 1.2$ & 441.57 & 2.59 & $-3.57(120)$ & 0.77 \\
\hline 3b & $>100$ & $60 \pm 22$ & $>100$ & 398.50 & 3.33 & $-3.70(79.7)$ & 0.76 \\
\hline $4 a$ & $>100$ & $58.0 \pm 5.7$ & $38.3 \pm 2.4$ & 427.54 & 2.52 & $-4.20(27.3)$ & 0.76 \\
\hline $4 b$ & $>100$ & $74.7 \pm 3.8$ & $27.0 \pm 2.6$ & 467.60 & 3.15 & $-4.42(17.8)$ & 0.54 \\
\hline 5 & $>100$ & $46 \pm 10$ & $57.3 \pm 5.5$ & 301.38 & 2.95 & $-4.05(26.8)$ & 0.64 \\
\hline 6 & $92.3 \pm 1.9$ & $>100$ & $21.3 \pm 2.7$ & 387.48 & 1.82 & $-4.20(24.5)$ & 0.78 \\
\hline 7 & $>100$ & $64 \pm 14$ & $15.0 \pm 1.5$ & 427.54 & 2.39 & $-3.98(44.3)$ & 0.76 \\
\hline 8 & $>100$ & $>100$ & $86.5 \pm 8.6$ & 174.20 & 1.58 & $-1.91(2140)$ & 0.57 \\
\hline 9 & $>100$ & $81 \pm 14$ & $>100$ & 207.61 & 2.04 & $-3.09(170)$ & 0.54 \\
\hline 10 & $>100$ & $52.3 \pm 7.8$ & $63.0 \pm 5.0$ & 231.60 & 3.46 & $-3.70(46.4)$ & 0.39 \\
\hline
\end{tabular}

Estimated values for $\log P, \log S$ and overall drug scores are also given (see text).

${ }^{a}$ Estimated by the ALOGPS 2.1 algorithm. ${ }^{22}$

${ }^{\mathrm{b}}$ Estimated by the Osiris Property Explorer. ${ }^{23}$ 
group of primaquine has been claimed to also have a key role on the drug's antimalarial activity. ${ }^{1,2}$ Possibly, the aliphatic primary amine has the appropriate $\mathrm{p} K_{\mathrm{a}}$ (ca. 10.6 and 9.7 for, respectively, butylamine and alanine ${ }^{24,25}$ ) for cellular internalization, whereas molecules devoid of primary amino groups or where such groups are aromatic ( $\mathrm{p} K_{\mathrm{a}}$ for aniline is ca. $4.2^{26}$ ) have not. Apparently, specific amino acid or oligopeptide transporters like hPept $1^{27,28}$ do not have a role here, or else better results would expected for $\mathbf{3 a , 6}$, and 7 on Caco- 2 cells, given their high expression of such transporters and their consequent use in intestinal absorption studies of compounds bearing oligopeptide moieties. ${ }^{27,28}$

At this preliminary stage, we can say that results are promising concerning compounds' specific anti-proliferative action against the MCF-7 cell line model of breast cancer. Though primaquine (1) and its $\mathrm{N}$-alanylprolyl derivative (7) were better than imidazoquine 3a against MCF-7 cells, the latter has the advantage of being both resistant against proteases (that promptly degrade the peptide moiety of 7) and oxidative deamination (the main metabolic process behind premature deactivation and low oral bioavailability of primaquine). ${ }^{12-19,29}$ Known algorithms ${ }^{22,23}$ were used to calculate parameters relevant to predict drug oral bioavailability, like $\log P$ or $\log S$ and to estimate the overall drug score of the test compounds (Table 1). Data show that imidazoquine $\mathbf{3 a}$ has not only the highest drug score of the set, but is also considerably soluble $(120 \mathrm{mg} / \mathrm{L})$ and has a $\log P$ value that falls within the optimal interval for gastric absorption $(2 \pm 1) 3^{30}$

Imidazoquines like $\mathbf{3 a}$ had already been found to display interesting antimalarial and anti-pneumocystic activities. ${ }^{16,17,19}$ Relevantly, such activities were consistently higher for those compounds derived from smaller amino acids (Gly or Ala, i.e., $\mathrm{R}^{1}$ and/or $\mathrm{R}^{2}=\mathrm{H}$ or $\mathrm{Me}$ ), as is the case of 3a. Moreover, the in vitro activity of imidazoquines $\mathbf{3}$ may become more pronounced in vivo due to their expectedly higher oral bioavailability as compared to $\mathbf{1}, \mathbf{6}$, and $\mathbf{7}$.

In view of the above, we believe that imidazoquines like 3a may constitute useful leads as multi-drugs against malaria, pneumocystic pneumonia (PCP), and breast cancer. Obviously, the development of novel anticancer agents is of undeniable value worldwide. Though breast cancer prevails in North-Western and temperate regions of the World, with relatively low incidence on African, South-American, and East-Asian regions where malaria is endemic, ${ }^{31}$ recent reports account for a significant increase of incidence in young Asian women ${ }^{32}$ and to alarming mortality rates among African women. ${ }^{33}$ So, we believe that discovery of multi-target drugs effective against cancer, malaria, and opportunistic infections like PCP, which may be deadly for HIV-infected persons, is especially relevant for those regions of the globe.

Finally, we must again outline that the mechanisms of both antimalarial and anti-proliferative action of quinolines are not fully understood. 4-Aminoquinolines, like chloroquine, are likely to exert their antimalarial action by impairment of hemozoin crystallization (the mechanism through which blood-stage parasites get rid of heme after digestion of host's hemoglobin), which explains why is chloroquine active only against intraerythrocytic parasites. $^{34}$ In what concerns chloroquine's anti-tumoral activity, DNA intercalation-induced apoptosis has been proposed ${ }^{35}$ but is still controversial. ${ }^{36}$

In the case of 8-aminoquinolines like primaquine (and, probably, imidazoquines 3), which are not active against intraerythrocytic parasites and exert an antimalarial role complementary to that of 4-aminoquinolines, the mechanism of action is certainly quite different. So far, studies on primaquine's mode of action suggests a key role for active quinone metabolites behind interference with the mitochondrial respiratory chain, as swelling of parasite's mitochondria and collapse of the mitochondrial membrane potential have been observed. ${ }^{2,34}$ Further, primaquine treatment is known to cause oxidative stress in liver, kidneys, and blood by generating reactive oxygen species (ROS). 2,37,38 ROS have a crucial role both on differentiation and suppression of hypoxic (e.g., breast) tumors ${ }^{39-44}$ and on lipid peroxidation, ${ }^{38,45}$ whose enhancement is known to be protective against breast cancer. ${ }^{45}$ In view of this, the anti-proliferative action of primaquine, $\mathbf{1}$, and derived imidazoquine, 3a, herein reported might be related to the intracellular generation of drug-derived ROS.

Ongoing in vitro redox and radical-scavenging properties of primaquine and imidazoquines $\mathbf{3}$, as well as in vivo anti-tumoral activity and oral bioavailability studies on the same compounds are in course and will be timely reported.

\section{Acknowledgments}

Thanks are due to the Portuguese Foundation for Science and Technology (FCT) for financial support through Project Grants PTDC/QUI/65142/2006, PTDC/QUI/65501/2006, CONC-REEQ/275/ QUI and REDE/1517/RMN/2005. N.V. and I.F. thank FCT for, respectively, Post-Doc Grant SFRH/BPD/48345/2008 and Ph.D. Grant SFRH/BD/38883/2007.

\section{Supplementary data}

Supplementary data associated with this article can be found, in the online version, at doi:10.1016/j.bmcl.2009.10.081.

\section{References and notes}

1. Rosenthal, P. J.. In Antimalarial Chemotherapy: Mechanisms of Action, Resistance and New Directions in Drug Discovery; Humana Press: Totowa, NJ, 2001.

2. Vale, N.; Moreira, R.; Gomes, P. Eur. J. Med. Chem. 2009, 44, 937.

3. Suryanaryana, V.; Meenakshi, J.; Kirandeep, K.; Premanand, P.; Sanjay, R. P.; Rahul, J. Med. Res. Rev. 2007, 27, 65.

4. Hoglund, I. P.; Silver, S.; Engstrom, M. T.; Salo, H.; Tauber, A.; Kyyronen, H. K.; Saarenketo, P.; Hoffren, A. M.; Kokko, K.; Pohjanoksa, K.; Sallinen, J.; Savola, J. M.; Wurster, S.; Kallatsa, O. A. J. Med. Chem. 2006, 49, 6351.

5. Zhou, Q.; Melkoumian, Z. K.; Lucktong, A.; Moniwa, M.; Davie, J. R.; Strobl, J. S. J. Biol Chem 2000, 275, 35256

6. Martirosyan, A. R.; Rahim-Bata, R.; Freeman, A. B.; Clarke, C. D.; Howard, R. L.; Strobl, J. S. Biochem. Pharmacol. 2004, 68, 1729.

7. Mahajan, A.; Yeh, S.; Nell, M.; van Rensburg, C. E. J.; Chibale, K. Bioorg. Med. Chem. Lett. 2007, 17, 5683.

8. Shi, A.; Nguyen, T. A.; Battina, S. K.; Rana, S.; Takemoto, D. J.; Chiang, P. K.; Hua, D. H. Bioorg. Med. Chem. Lett. 2008, 18, 3364.

9. Gunjan, G.; Takahiro, O.; Aibin, S.; Duy, H. H.; Thu Annelise, N. Drug Dev. Res. 2008, 69, 526 .

10. Jones, M. Mercer, A. E - Stocks, P. A. La Pensée, L. J. I - Cosstick, R. Park, B. K. Kennedy, M. E.; Piantanida, I.; Ward, S. A.; Davies, J.; Bray, P. G.; Rawe, S. L.; Baird, J.; Charidza, T.; Janneh, O.; O'Neill, P. M. Bioorg. Med. Chem. Lett. 2009, 19, 2033.

11. Rosenthal, A. S.; Chen, X.; Liu, J. O.; West, D. C.; Hergenrother, P. J.; Shapiro, T. A.; Posner, G. H. J. Med. Chem. 2009, 52, 1198.

12. Araújo, M. J.; Bom, J.; Capela, R.; Casimiro, C.; Chambel, P.; Gomes, P.; Iley, J.; Lopes, F. Morais, J.; Moreira, R.; de Oliveira, E.; do Rosario, V.; Vale, N. J. Med. Chem. 2005, 48 888.

13. Chambel, P.; Capela, R.; Lopes, F.; Iley, J.; Morais, J.; Gouveia, L.; Gomes, J. R. B.; Gomes, P.; Moreira, R. Tetrahedron 2006, 62, 9883.

14. Ferraz, R.; Gomes, J. R. B.; de Oliveira, E.; Moreira, R.; Gomes, P. J. Org. Chem 2007, 72, 4189 .

15. Gomes, P.; Araújo, M. J.; Rodrigues, M.; Vale, N.; Azevedo, Z.; Iley, J.; Chambel, P.; Morais, J.; Moreira, R. Tetrahedron 2004, 60, 5551.

16. Vale, N.; Collins, M. S.; Gut, J.; Ferraz, R.; Rosenthal, P. J.; Cushion, M. T. Moreira, R.; Gomes, P. Bioorg. Med. Chem. Lett. 2008, 18, 485

17. Vale, N.; Matos, J.; Gut, J.; Nogueira, F.; do Rosario, V.; Rosenthal, P. J.; Moreira R.; Gomes, P. Bioorg. Med. Chem. Lett. 2008, 18, 4150.

18. Vale, N.; Nogueira, F.; do Rosário, V. E.; Gomes, P.; Moreira, R. Eur. J. Med. Chem. 2009, 44, 2506.

19. Vale, N.; Prudêncio, M.; Marques, C. A.; Collins, M. S.; Gut, J.; Nogueira, F.; Matos, J.; Rosenthal, P. J.; Cushion, M. T.; do Rosário, V. E.; Mota, M. M.; Moreira, R.; Gomes, P. J. Med. Chem. ahead-of-print (doi:10.1021/jm900738c).

20. Skehan, P.; Storeng, R.; Scudiero, D.; Monks, A.; McMahon, J.; Vistica, D.; Warren, J. T.; Bokesch, H.; Kenney, S.; Boyd, M. R. J. Natl. Cancer Inst. 1990, 82 1107.

21. Monks, A.; Scudiero, D.; Skehan, P.; Shoemaker, R.; Paul, K.; Vistica, D.; Hose, C.; Langley, J.; Cronise, P.; Vaigro-Wolff, A., et al J. Natl. Cancer Inst. 1991, 83, 757.

22. http://www.vcclab.org/lab/alogps.

23. http://www.organic-chemistry.org/prog/peo

24. Hall, H. K. J. Am. Chem. Soc. 2002, 79, 5441. 
25. Dawson, R. M. C.; Elliott, D. C.; Elliott, W. H.; Jones, K. M. Data for Biochemical Research; Oxford University Press, 1959.

26. Elliott, J. J.; Mason, S. F. J. Chem. Soc. (Resumed) 1959, 2352.

27. Santos, C.; Morais, J.; Gouveia, L.; De Clercq, E.; Pannecouque, C.; Nielsen, C. U.; Steffansen, B.; Moreira, R.; Gomes, P. ChemMedChem 2008, 3, 970.

28. Santos, C. R.; Capela, R.; Pereira, C. S. G. P.; Valente, E.; Gouveia, L.; Pannecouque, C.; De Clercq, E.; Moreira, R.; Gomes, P. Eur. J. Med. Chem. 2009, 44, 2339.

29. Portela, M. J.; Moreira, R.; Valente, E.; Constantino, L.; Iley, J.; Pinto, J.; Rosa, R.; Cravo, P.; do Rosario, V. E. Pharm. Res. 1999, 16, 949.

30. Handbook of Preformulation: Chemical, Biological, and Botanical Drugs; Niazi, S. K., Ed.; CRC Press, 2006.

31. Parkin, D. M. Lancet Oncol. 2001, 2, 533.

32. Yip, A. Y.; Chow, L. W. Breast Cancer 2006, 13, 192.

33. Parkin, D. M.; Leticia, M. G. F. Breast J. 2006, 12, S70.
34. Foley, M.; Tilley, L. Pharmacol. Ther. 1998, 79, 55.

35. Zhou, Q.; McCracken, M. A.; Strobl, J. S. Breast Cancer 2002, 75, 107.

36. Savarino, A.; Lucia, M. B.; Giordano, F.; Cauda, R. Lancet Oncol. 2006, 7, 792.

37. Vazquez-Vivar, J.; Augusto, O. Free Radical Res. 1990, 7, 383.

38. Šimunović, M.; Perković, I.; Zorc, B.; Ester, K.; Kralj, M.; Hadjipavlou-Litina, D.; Pontiki, E. Bioorg. Med. Chem. 2009, 17, 5605.

39. Pugh, C. W.; Gleadle, J. I.; Maxwell, P. H. Breast Cancer Res. 2001, 3, 313.

40. Knowles, H. J.; Harris, A. L. Breast Cancer Res. 2001, 3, 318.

41. Williams, K. J.; Cowen, R. L.; Stratford, I. J. Breast Cancer Res. 2001, 3, 328.

42. Van den Eynden, G. G.; Van der Auwera, I.; Van Laere, S. J.; Colpaert, C. G.; Turley, H.; Harris, A. L.; Van Dam, P.; Dirix, L. Y.; Vermeulen, P. B.; Van Marck, E. A. Br. J. Cancer 2005, 93, 1128.

43. Kim, J.-W.; Gao, P.; Dang, C. V. Cancer Metast. Rev. 2007, 26, 291.

44. Milani, M.; Harris, A. L. Eur. J. Cancer 2008, 44, 2766.

45. Gago-Domíngeuz, M.; Jiang, X.; Castelao, J. E. Breast Cancer J. 2007, 9, 201. 